International Journal of Research in Business and

\title{
Causal Relationship between Construction Production and GDP in Turkey
}

\section{Hakkı Kutay BOLKOL}

Research Assistant, Istanbul 29 Mayls University

\begin{abstract}
This study empirically investigates the causal relationship between construction production and GDP for Turkey during 2005Q1-2013Q4 period. Because it is found that, there is no cointegration which means there is no long run relationship between variables, VAR Granger Causality Method is used to test the causality in short run. The findings reveal that, the causality runs from GDP to Building Production and Building Production to Non-Building Production (i.e. bidirectional relationship). Findings of this paper suggest that, because there is no long run relationship between Construction Production (Building and Non-Building) and GDP and also in short run the causality runs from GDP to Construction Production, the growth strategy based on mainly Construction Sector growth is not a good idea for Turkey.
\end{abstract}

Key Words: Construction Sector; Construction Production; Economic Growth; Turkey; VAR Granger Causality

\section{JEL classification: $\mathrm{C} 32 ; \mathrm{E} 62$}

\section{Introduction}

Construction sector is one of the significant sector in Turkish economy. It is also related to many other industries. It is said that, construction sector has many subsectors. Therefore, it is called driver of economic growth. The sector consists of building and non-building construction activities. Because of the input that sector uses and the contribution to employment, it is accepted as one of the most powerful sector in economy.

Non-building construction activities like; roads, bridges, ports, dams, highways, railways, power systems etc. and building construction activities like; residential buildings, hospitals, schools, trade centers, factories etc. are called investment goods. These goods also make contribution to production of other goods and services that's why they create value added. Furthermore, the inputs that are used in construction sector are also related to many other sectors and this is called backward linkage. Moreover, an increase in construction volume may also cause an increase in the volume of aggregate economy what is called forward linkage. For this reason it can be said that, construction sector is a leader sector in economy.

What's more, as it is said above, it makes important contribution to employment since it employs both unskilled and skilled labors. Furthermore, providing infrastructure, sanctuaries, schools, hospitals, cultural centers, libraries etc., the sector plays a significant role in socio-economic development. 
Also many studies suggest that, construction sector is very important since it is major source of economic growth and development especially for developing countries like Turkey. It is better to give some statistical tables to see how construction sector is related to economic growth and employment.

Table 1.1 shows the share of construction sector in GDP (Gross Domestic Product) in the years between 2005 and 2013 with constant prices of 1998. 2014 is not included because there is no available data for the last quarter of the year 2014 during the analysis was made. Subsequent empirical findings will also give the result within these years. From the table, it can be seen that, the share of construction sector is about $6 \%$.

To see the relation better Table 1.2 shows the growth rates of GDP and Construction sector with constant prices of 1998. One can comment that, construction sector is highly dependent to GDP because it can be seen that, when there is a decrease in growth of GDP, construction sector growth declines more than GDP with a multiplier effect or when there is an increase in growth of GDP, construction sector growth increases more than GDP.

Table 1.3 shows the share of construction sector in employment process and total rate of unemployment. Maybe by looking Table 1.1 and Table 1.2, one can state that, construction is highly dependent to GDP. Since it has about $6 \%$ share in GDP, it cannot be said that, it affect GDP alone. However, by looking Table 1.3, it can be said that, when there is a considerable increase in the rate of construction employment, total unemployment decreases especially in the years between 2005-2006 and 2010-2011. But the question is that; "Is this situation permanent?" Because generally unskilled workers in construction sector are seasonally workers and when project ends they have to look for another project to work, the contribution of construction sector to general employment is a little bit ambiguous especially in long-run. So it can be said that, contribution of construction sector to economic growth through the channel of employment is a controversial issue.

Table 1.1: GDP and the Share of Construction Sector in GDP (2005-2013)

\begin{tabular}{|c|c|c|c|}
\hline Year & GDP (million TL) & $\begin{array}{l}\begin{array}{l}\text { Construction } \\
\text { (million TL) }\end{array} \\
\text { Sector }\end{array}$ & $\begin{array}{l}\text { Share of Construction } \\
\text { Sector in GDP }\end{array}$ \\
\hline 2005 & 90500 & 5250 & $5.8 \%$ \\
\hline 2006 & 96738 & 6221 & $6.4 \%$ \\
\hline 2007 & 101225 & 6574 & $6.5 \%$ \\
\hline 2008 & 101922 & 6041 & $5.9 \%$ \\
\hline 2009 & 97003 & 5067 & $5.2 \%$ \\
\hline 2010 & 105886 & 5996 & $5.7 \%$ \\
\hline 2011 & 115175 & 6688 & $5.8 \%$ \\
\hline 2012 & 117625 & 6726 & $5.7 \%$ \\
\hline 2013 & 122556 & 7221 & $5.9 \%$ \\
\hline
\end{tabular}

Source: TURKSTAT (Turkish Statistical Institute)

Table 1.2: Growth Rates of GDP and Construction Sector

\begin{tabular}{|l|l|l|}
\hline Years & Growth Rate of GDP (\%) & $\begin{array}{l}\text { Growth Rate of Construction } \\
\text { Sector (\%) }\end{array}$ \\
\hline $\mathbf{2 0 0 5}$ & 8,4 & 9,3 \\
\hline $\mathbf{2 0 0 6}$ & 6,9 & 18,5 \\
\hline $\mathbf{2 0 0 7}$ & 4,7 & 5,7 \\
\hline $\mathbf{2 0 0 8}$ & 0,7 & $-8,1$ \\
\hline $\mathbf{2 0 0 9}$ & $-4,8$ & $-16,1$ \\
\hline $\mathbf{2 0 1 0}$ & 9,2 & 18,3 \\
\hline $\mathbf{2 0 1 1}$ & 8,5 & 11,3 \\
\hline $\mathbf{2 0 1 2}$ & 2,2 & 0,6 \\
\hline $\mathbf{2 0 1 3}$ & 4,0 & 7,1 \\
\hline
\end{tabular}

Source: TURKSTAT (Turkish Statistical Institute) 
Table 1.1: The Share of Construction Sector in Employment

\begin{tabular}{|l|l|l|}
\hline Years & Construction Employment (\%) & $\begin{array}{l}\text { Unemployment in General } \\
\text { Economy (\%) }\end{array}$ \\
\hline $\mathbf{2 0 0 5}$ & 5,5 & 10,6 \\
\hline $\mathbf{2 0 0 6}$ & 5,9 & 10,2 \\
\hline $\mathbf{2 0 0 7}$ & 5,9 & 10,3 \\
\hline $\mathbf{2 0 0 8}$ & 5,9 & 11 \\
\hline $\mathbf{2 0 0 9}$ & 6,1 & 14 \\
\hline $\mathbf{2 0 1 0}$ & 6,3 & 11,9 \\
\hline $\mathbf{2 0 1 1}$ & 7,0 & 9,8 \\
\hline $\mathbf{2 0 1 2}$ & 6,9 & 9,2 \\
\hline $\mathbf{2 0 1 3}$ & 7,0 & 9,7 \\
\hline
\end{tabular}

Source: TURKSTAT (Turkish Statistical Institute)

From the tables, it can be said that; construction activities seem to be dependent to GDP. However, in section 4, called Empirical Results, the causality between GDP and construction sector production is analyzed empirically. Rest of the paper is organized as follows; section 2, 3 and 5 respectively present; Literature Review, Methods and Data, Conclusion and Recommendations.

\section{Literature Review}

There are numerous studies that examine the relationship between construction activities and economic growth that is based on GDP (Gross Domestic Product). But there is no certain conclusion about this issue. Every study includes its own specific results. At first step, one may think that the situation may vary for country to country. However, in literature it varies even for same country because of techniques that are used in studies.

In literature which is related with the construction sector as well as the economic growth and development, there are pioneer studies such as Turin (1978) and more recent one, Bon (1992). Turin's (1978) study largely includes the developing countries and he founds positively S-shaped relation between the share of construction sector in GDP and per capita GDP. And Turin concludes that the share of construction sector increases as GDP per capita increases. Bon (1992) finds different results than Turin. Bon states that the problem of Turin's study is the dominance of developing countries in his sample and that's why positively S-shaped relation is found. He includes less developed countries, newly-industrialized countries and advanced-industrialized countries to his sample and he finds inverted U-shaped relation which starts with less developed countries and ends with advanced-industrialized countries between the share of construction in Gross National Product (GNP) and GNP per capita. Bon states that, in less developed countries and newly industrialized countries, the share of construction sector in GNP increase with GNP per capita but after the level of newly-industrialized country status and the road to reach advanced-industrialized country status, the share of construction sector in GNP decreases as GNP per capita increases. That's why he concludes that there is inverted Ushaped relationship between the share of construction sector in GNP and GNP per capita.

There are some studies about construction sector and economic growth related with Turkey, for instance, Kaya et al. (2013) examines the role of construction sector in economic growth for Turkey case. In this study, construction investment divided into two as public construction investment and private construction investment. The determinant of economic growth is GDP for this study. In order to investigate the relationship, Granger Causality Method is used. And it is found that, the causality runs public sector construction investments to GDP and GDP to private sector construction investments. In other words, public sector construction investments affect GDP and GDP affects private sector construction investments. Consequently, the study suggests that, construction sector is very significant for sustainable economic growth.

Ozkan et al. (2012) also work on Turkey case and they examines causal relationship between construction investment policy and economic growth in Turkey. The study shows the importance of construction sector by putting the emphasis on a wide range of subsectors which construction sector has. This work divides construction sector into three as public construction investment, private construction investment and infrastructure investment. It is found that, there is cointegration (long run relationship) between public construction investment and economic growth. There is 


\section{Bolkol /International Journal of Research in Business and Social Science \\ Vol 4, No 3, 2015 ISSN: 2147-4478}

also cointegration between infrastructure investment and economic growth. But there is no cointegration between private construction investment and economic growth. In causality analysis, it is found that, there is bidirectional relationship between both infrastructure investment and economic growth, and public construction investment and economic growth. Consequently, this study suggests that, in long run public construction investment affects economic growth positively. Therefore, government should give importance to that issue.

It is also important to look the relationship between construction sector and economic growth for other developing countries. Mallick and Mahalik (2010) investigates the role of construction sector in India's economic growth. According to their study, dominant influence of capital stock blurred or neutralized the impact of construction sector. However, when capital stock dropped out from the equation, the significance of construction sector in economic growth increases sharply. And this work puts emphasis on the employment that construction sector provides. It is suggested that, when employment of construction sector increases, output also increases and this provides an increase in economic growth. However, it is emphasized that, these effects are only valid in short-run.

Tiwari (2011) works on the causal relationship between construction flows and economic growth in India under static and dynamic framework. In static analysis it is indicated that, there is bidirectional causality between construction flows and economic growth. But in dynamic analysis it is found that, construction flows affect economic growth positively in short run but long run effect is negative. And economic growth affects construction flows negatively in short run but the effect in long run is positive. Consequently, this study suggests that, in short run Indian government can focus on development of construction sector as it has positive effect on economic growth. However, in long run Indian government should gradually cut down her budget expenditure on construction.

Chang and Nieh (2004) study the causal link between construction activity and economic growth in Taiwan. It is found that, there is cointegration between construction activity and economic growth. According to work, there is unidirectional causality that runs construction activity to economic growth both in short run and long run. And it is said that, this result is consistent both with Neoclassical and Keynesian view since economic growth is determined by exogenous factors.

Khan (2008) examines the role of construction sector in economic growth for Pakistan economy. It is said that, although construction sector is driver of economic growth in developing countries, in Pakistan it is most neglected sector. In empirical analysis it is found that, there is cointegration relation between construction sector and economic growth means they have long run relationship. Causality runs from construction to economic growth which can be stated that, there is forward linkage.

Tse and Ganesan (1997) study the causal relationship between construction flows and GDP for Hong Kong economy. The purpose of this work is to examine specific lead-lag relationship between construction flow and GDP. It is found that, there is unidirectional relationship that runs GDP to construction flow in short run. According to analysis, demand for construction work is not autonomous rather it is determined by GDP. This results suggest that, GDP is more volatile than construction flows since GDP affects construction flows. And it is contrary to the general view which states that construction is more volatile than GDP. The reason for this explained in the way that, when there is a decrease in GDP, income decreases and this affects credit supply conditions. And when credit supply decreases, construction activities decreases. As a result the work recommends that, government should affect the output to influence construction activity.

Choy et al. (2011) examines the property investment, construction and economic growth for Malaysia. The study investigates the causal relationships and it is found that construction activities affect GDP positively and GDP affects property investment ${ }^{1}$ positively. These causalities are unidirectional. The work concludes that, since Malaysia is a developing country, construction activities are important for economic growth.

Anaman and Amponsah (2007) work on the causality between construction industry growth and economic growth in Ghana. In empirical analysis they include political stability as dummy variable since in some periods Ghana experienced military coups. And the study complains the lack of interest to construction sector although it is $3^{\text {rd }}$ largest sector in Ghana. Empirically, there is no cointegration found between construction production, economic growth and political stability. That's why, short run analysis is investigated. And it is found that, political stability and construction production affect GDP positively. Moreover, political stability affects also construction production in a

\footnotetext{
${ }^{1}$ Property investment is a source of capital accumulation.
} 


\section{Bolkol /International Journal of Research in Business and Social Science \\ Vol 4, No 3, 2015 ISSN: 2147-4478}

positive direction. At the end, the study put the emphasis on the importance of construction sector for economic growth but also it is stated that, there may be some problems related with funding and negotiations.

\section{Research and Methodology}

In this study, causal relationship between construction production and GDP is analyzed for the case of Turkey. For this empirical work, E-Views 8 econometric software is used. It is time series work for the period 2005Q1-2013Q4. The variables are GDP, Building Production and Non-Building Production.

All variables are expressed in natural logarithms in order to allow the estimated coefficients to be considered as the elasticity of the relevant variables. Furthermore, if the change in a variable is relatively small, the difference of the logarithms of the variable is approximately equal the growth rate. And it is generally convenient to use growth rates for economic relationships. Therefore, natural logarithmic version of the variables is used.

For this study, following abbreviations are used like; LGDP for natural logarithm of Gross Domestic Product, LBUILD for natural logarithm of Building Production, LNBUILD for natural logarithm of Non-Building Production.

The data is taken from TURKSTAT (Turkish Statistical Institute). And the variables BUILD and NBUILD are in index form with the base year of 2010 and already seasonally adjusted. Therefore, for equalizing variables, GDP transformed into index form with the base year of 2010 and using E-Views Census X-13 procedure, it is get the form of seasonally adjusted variable.

In order to explore causal relationship between GDP, Building Production and Non-Building Production, Granger Causality method is used.

If the variables are not stationary in their levels, it should be analyzed whether the variables are trend stationary or difference stationary because if one variable is trend stationary and one applies differencing method to trend stationary variable, over differencing problem occurs and this causes misinterpretation of the model.

For unit root test, PP (Phillips-Perron) Unit Root Test is used for this analysis because PP Unit Root Tests are robust the general forms of Heteroscedasticity in error term. Another advantage is that, the user does not have to specify a lag length for the test regression (Zivot and Wang, 2006, p. 127).

After that, cointegration analysis should be done for the variables that are integrated of same order. For cointegration analysis Johansen Cointegration Test is used. For the case of no cointegration, which means that, there is no long run relationship, VAR model Granger Causality should be constructed for looking causal relationship in short run. However, one should always keep in mind that VAR model needs stationarity. If the variables are not stationary in level that means differencing or de-trending method should be used before constructing VAR model. After doing these steps, if one wants to be sure of the stability of the VAR model, he/she should look AR Roots Table or/and Graph. For stable VAR, all the roots in the system should be inside the unit circle.

Furthermore it is also important to determine the optimal lag length. Ivanov and Kilian (2005) suggest that, if sample size is smaller than 120, Schwarz Information Criterion (SC) is more accurate for quarterly VAR models that's why in order to select ideal lag length, Shwarz Information Criterion is used.

At the end it is important to check diagnostic tests (Normality Tests, Serial Correlation Tests, Heteroscedasticity Tests) to see whether the model is well behaved or not.

\section{Empirical Findings}

For testing trend stationarity, 3 filter methods are used. These are; Hodrick-Prescott (HP), Baxter-King (BK) and Corbae-Ouliaris first difference (FD) filters. 3 methods used to be sure about whether the variables are trend stationary or not. After de-trending the variables, PP Unit Root Test is used.

Table 2.1 indicates that, according to all 3 methods of de-trending, null hypothesis, which indicates that there exists unit root, is accepted because all the probability values are bigger than $5 \%$ criteria. That means the variables are not trend stationary. So it can be said that, differencing method should be used in order to determine the integration order of the variables. 
Table 2.1: Testing Trend Stationary

\begin{tabular}{|c|c|c|c|c|}
\hline & & & PP Unit Root Test Results & \\
\hline Variables & Cases & HP Filter & BK Filter & FD Filter \\
\hline \multirow[t]{2}{*}{ LGDP } & Intercept & 0.9770 & 0.3680 & 0.2564 \\
\hline & $\begin{array}{ll}\text { Trend } & \& \\
\text { Intercept }\end{array}$ & 0.8615 & 0.9655 & 0.5667 \\
\hline \multirow[t]{2}{*}{ LBUILD } & Intercept & 1.000 & 0.4113 & 0.3439 \\
\hline & $\begin{array}{ll}\text { Trend } & \& \\
\text { Intercept } & \end{array}$ & 0.9992 & 0.9832 & 0.6553 \\
\hline \multirow[t]{2}{*}{ LNBUILD } & Intercept & 0.0948 & 0.7108 & 0.1801 \\
\hline & $\begin{array}{l}\text { Trend } \\
\text { Intercept }\end{array}$ & 0.1072 & 0.8332 & 0.4350 \\
\hline
\end{tabular}

Note: Numbers show the probability values.

So when differencing method is used, Table 2.2 shows that, LGDP and LNBUILD are integrated of order 1. However, LBUILD is integrated of order 2.

Table 2.2: PP Unit Root Test Results ${ }^{2}$

\begin{tabular}{|c|c|c|c|c|c|}
\hline \multirow[b]{2}{*}{ Variables } & \multirow[b]{2}{*}{ Cases } & \multicolumn{3}{|c|}{ PP Unit Root Test Results } & \multirow{2}{*}{ Decision } \\
\hline & & Level & $1^{\text {st }}$ Difference & $2^{\text {nd }}$ Difference & \\
\hline \multirow[t]{2}{*}{ LGDP } & Intercept & 0.8229 & $0.0344 * *$ & $0.0000^{* * *}$ & \multirow[b]{2}{*}{$\mathrm{I}(1)$} \\
\hline & $\begin{array}{l}\text { Trend } \quad \& \\
\text { Intercept }\end{array}$ & 0.4389 & 0.1219 & $0.0000^{* * *}$ & \\
\hline \multirow[t]{2}{*}{ LBUILD } & Intercept & 0.3203 & 0.2886 & $0.0133 * *$ & \multirow[t]{2}{*}{$\mathrm{I}(2)$} \\
\hline & $\begin{array}{ll}\text { Trend } & \& \\
\text { Intercept } & \\
\end{array}$ & 0.6133 & 0.6070 & $0.0565^{*}$ & \\
\hline \multirow[t]{2}{*}{ LNBUILD } & Intercept & 0.8765 & $0.0000^{* * *}$ & --- & \multirow[t]{2}{*}{$\mathrm{I}(1)$} \\
\hline & $\begin{array}{ll}\text { Trend } & \& \\
\text { Intercept } & \\
\end{array}$ & 0.2317 & $0.0001 * * *$ & -- & \\
\hline
\end{tabular}

Note: $* * *, * *, *$ denotes stationary at level $\% 1, \% 5$, and $\% 10$ respectively.

According to table 2.2, LGDP and LNBUILD are integrated of same order. Therefore, cointegration analysis should be done for these variables to see whether there exists long run relationship between these two variables or not.

\footnotetext{
${ }^{2}$ Numbers in table shows the probability values.
} 
Table 2.3 shows the optimal lag length according to Schwarz Information Criterion (SC). And it suggests that, optimal lag length, for these two variables, is 4 .

Table 2.3: VAR Lag Order Selection Criteria for the Variables; LGDP and LNBUILD

\begin{tabular}{|l|l|l|l|l|l|l|}
\hline Lags & $\mathbf{1}$ & $\mathbf{2}$ & $\mathbf{3}$ & $\mathbf{4}$ & $\mathbf{5}$ & $\mathbf{6}$ \\
\hline $\begin{array}{l}\text { Schwarz } \\
\begin{array}{l}\text { Information } \\
\text { criteria } \\
\text { (SC) }\end{array}\end{array}$ & -7.615689 & -7.640302 & -7.530023 & $-7.756590^{*}$ & -7.535009 & -7.640117 \\
\hline
\end{tabular}

Note: * shows the optimal lag length for SC.

After determining the optimal lag length, in table 2.4, Johansen Cointegration Test is applied for the variables; LGDP and LNBUILD. Johansen approach determines the number of cointegrated vectors for any given number of nonstationary variables of the same order that's why this test must be applied in level forms of the variables. To explain the procedure, it is better to say that the sign of "**" suggests, the optimal data trend according to Information Criterions. And because Schwarz is selected for our analysis, it shows two different data trends. Therefore, in order to determine the data trend, the help of Akaike Information Criterion is taken. And according to both Schwarz and Akaike, linear intercept and trend is suggested since smallest information criterion value is the best for models. Furthermore, according to both max-eigen and trace statistics, there is no cointegration between these two variables for our case of linear intercept and trend.

Table 2.4: Cointegration Results for the Variables; LGDP and LNBUILD

\begin{tabular}{|l|l|l|l|l|l|}
\hline Data Trend & None & None & Linear & Linear & Quadratic \\
\hline Test Type & No Intercept & Intercept & Intercept & Intercept & Intercept \\
\hline & No Trend & No Trend & No Trend & Trend & Trend \\
\hline Trace & 1 & 2 & 0 & 0 & 2 \\
\hline Max-Eig & 0 & 0 & 0 & 0 & 0 \\
\hline
\end{tabular}

According to Akaike Information Criteria

\begin{tabular}{|l|l|l|l|l|l|}
\hline 0 & -7.630646 & -7.630646 & -7.825293 & -7.825293 & -7.712431 \\
\hline 1 & -7.710706 & -7.685133 & -7.907552 & $-7.979072 *$ & -7.928523 \\
\hline 2 & -7.534559 & -7.676853 & -7.676853 & -7.907201 & -7.907201 \\
\hline
\end{tabular}

According to Schwarz Information Criteria

\begin{tabular}{|l|l|l|l|l|l|}
\hline 0 & -6.890524 & -6.890524 & $-6.992655^{*}$ & $-6.992655^{*}$ & -6.787278 \\
\hline 1 & -6.785553 & -6.713723 & -6.889883 & -6.915146 & -6.818339 \\
\hline 2 & -6.424376 & -6.474154 & -6.474154 & -6.611987 & -6.611987 \\
\hline
\end{tabular}

By looking these results, because there is no cointegration or long run relationship between these variables, we should construct VAR model Granger Causality to look the causality between these variables in short run. And because VAR model needs stationarity, the difference forms of variables are used. We have two variables that are integrated of order 1 and one variable that is integrated of order 2.

Before the testing procedure, lag structure should be determined. In all analyses of this study Schwarz Information Criterion is used. Table 2.5 shows that, the optimal lag length is 2 for this case, for the variables DLGDP, 
DDLBUILD and DLNBUILD. The term "D" means difference. Because LGDP and LNBUILD are integrated of order one, they have 1 "D" meaning that they get stationary after taking first difference and since LBUILD is integrated of order two, it has 2 "D" meaning that it gets stationary after taking second difference.

Table 2.5: VAR Lag Order Selection Criteria for the Variables; DLGDP, DDLBUILD, DLNBUILD

\begin{tabular}{|l|l|l|l|l|l|l|}
\hline Lags & $\mathbf{1}$ & $\mathbf{2}$ & $\mathbf{3}$ & $\mathbf{4}$ & $\mathbf{5}$ & $\mathbf{6}$ \\
\hline $\begin{array}{l}\text { Schwarz } \\
\text { Information } \\
\text { Criteria } \\
\text { (SC) }\end{array}$ & -12.62650 & $-13.14295^{*}$ & -12.52652 & -12.10235 & -11.78079 & -11.64653 \\
\hline
\end{tabular}

Note: * shows the optimal lag length for SC

Table 2.6 shows the result of VAR Granger Causality. To explain the commenting procedure; if probability value is smaller than 5\% that means that, there exists causality. And according to table it can be said that, the causality runs DLGDP to DDLBUILD and DDLBUILD to DLNBUILD. It is very significant to state that, because VAR Granger Causality is short run analysis, these results are only valid for short-run.

Figure 1.1 also indicates that, GDP Granger causes Building Production and Building Production Granger causes Non-Building Production in short run but not vice versa.

Table 2.6: VAR Granger Causality for the Variables; DLGDP, DDLBUILD, DLNBUILD

\begin{tabular}{|l|l|l|l|}
\hline Null Hypothesis & Test Statistics & Probability Value & Result \\
\hline $\begin{array}{l}\text { DDLBUILD Does Not } \\
\text { Granger Cause DLGDP }\end{array}$ & Chi-sq $=0.751604$ & 0.6867 & Accepted \\
\hline $\begin{array}{l}\text { DLNBUILD Does Not } \\
\text { Granger Cause DLGDP }\end{array}$ & Chi-sq $=0.040314$ & 0.98009 & Accepted \\
\hline $\begin{array}{l}\text { DLGDP Does Not Granger } \\
\text { Cause DDLBUILD Dees Not }\end{array}$ & Chi-sq $=9.234300$ & 0.0099 & Rejected \\
\hline $\begin{array}{l}\text { DLNBUILD Does } \\
\text { Granger Cause DDLBUILD }\end{array}$ & Chi-sq $=2.821269$ & 0.2440 & Accepted \\
\hline $\begin{array}{l}\text { DLGDP Does Not Granger } \\
\text { Cause DLNBUILD }\end{array}$ & Chi-sq $=0.613864$ & 0.7357 & Accepted \\
\hline $\begin{array}{l}\text { DDLBUILD Does Not } \\
\text { Granger Cause DLNBUILD }\end{array}$ & Chi-sq $=9.950698$ & 0.0069 & Rejected \\
\hline
\end{tabular}

Note: If the probability value is more than $5 \%$ that means null hypothesis must be accepted or vice versa.

\section{GDP $\rightarrow$ BUILDING PRODUCTION $\rightarrow$ NON-NUILDING PRODUCTION}

Figure 1.1: Direction of Causality

After constructing VAR Model Granger Causality, the stability of VAR is tested since in order to get credible results, the stability of VAR Model is significant. Table2.7 indicates that, all the roots are smaller than 1 meaning that they are inside the unit circle. While making interpretation, one should be look the values under the Modulus since it gives the result with absolute value. Consequently, it can be easily said that this VAR Model is stable. 
Table 2.7: AR Root Table for the Variables; DLGDP, DDLBUILD, DLNBUILD

\begin{tabular}{|l|l|}
\hline Root & Modulus \\
\hline $0.546974-0.429066 \mathrm{i}$ & 0.695182 \\
\hline $0.546974+0.429066 \mathrm{i}$ & 0.695182 \\
\hline$-0.306876-0.466516 \mathrm{i}$ & 0.558400 \\
\hline$-0.306876+0.466516 \mathrm{i}$ & 0.558400 \\
\hline $0.148100-0.470445 \mathrm{i}$ & 0.493206 \\
\hline $0.148100+0.470445 \mathrm{i}$ & 0.493206 \\
\hline
\end{tabular}

Figure 1.2 also indicates that, all the roots are inside the unit circle and the model is stable.

After being sure that the model is stable, diagnostic tests should be done to see whether the model is well-behaved or not. Table 2.8 shows the diagnostic tests. If the results are interpreted respectively, firstly, the null hypothesis of VAR Residual Heteroscedasticity Test indicates that, there is no Heteroscedasticity because the probability value is bigger than $5 \%$, the null hypothesis is accepted. That means, there is no Heteroscedasticity for both without cross terms and with cross terms. Secondly, VAR Residual Normality Test (Jarque Bera) result indicates that, the null hypothesis which states that, errors are normally distributed, is accepted because the probability value is more than $5 \%$. Thirdly, the result of VAR Residual Serial Correlation LM Test (lags 1 to 12) indicates that, the null hypothesis which states that, there is no serial correlation, is accepted since all the probabilities are bigger than $5 \%$. This also means that, there is no serial correlation. Consequently, according to diagnostic tests results, it can be said that, the model is wellbehaved $^{3}$.

\section{Inverse Roots of AR Characteristic Polynomial}

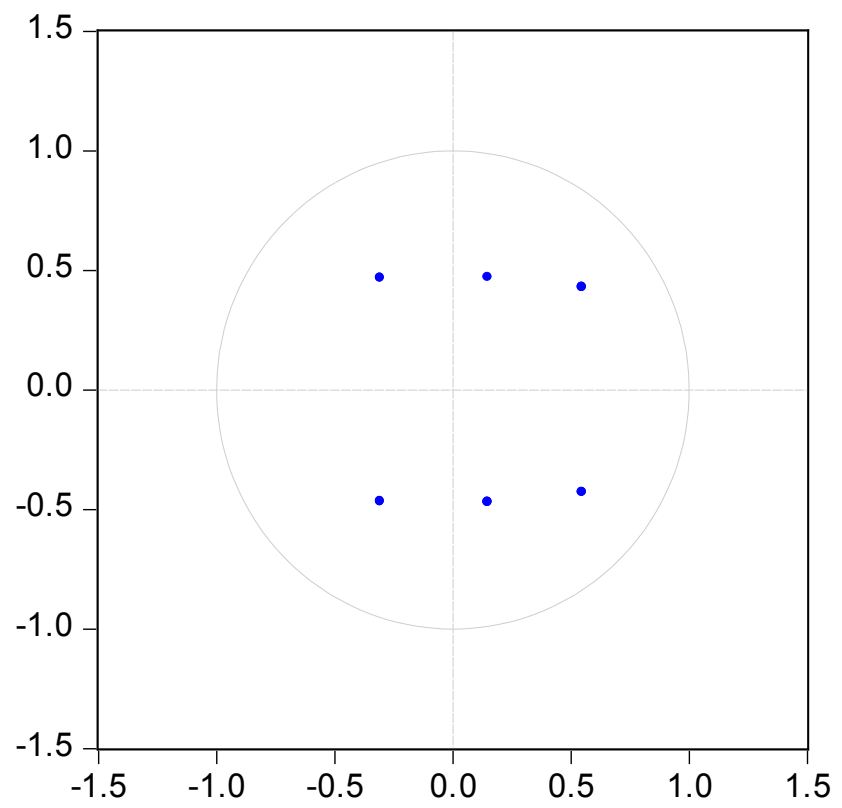

Figure 1.2: AR Roots Graph

\footnotetext{
${ }^{3}$ The errors are normally distributed, non-heteroscedastic and free of autocorrelation.
} 
Table 2.8: Diagnostic Tests

\begin{tabular}{|l|l|l|}
\hline Test & Test Statistics & P-Value \\
\hline $\begin{array}{l}\text { VAR Residual Heteroscedasticity } \\
\text { Test (without cross terms) }\end{array}$ & Chi-sq $=73.57968$ & \\
\hline $\begin{array}{l}\text { VAR Residual Heteroscedasticity } \\
\text { Test (with cross terms) }\end{array}$ & Chi-sq $=169.8307$ & 0.4262 \\
\hline VAR Residual Normality Test & & 0.3209 \\
(Jarque Bera) & Chi-sq $=11.79265$ & \\
\hline VAR Residual Serial Correlation & $\mathrm{LM}=11.58351$ & 0.0668 \\
LM Test (lags 1 to 12) & $\mathrm{LM}=13.05902$ & 0.2378 \\
& $\mathrm{LM}=11.21345$ & 0.1600 \\
& $\mathrm{LM}=4.117417$ & 0.2614 \\
& $\mathrm{LM}=6.606829$ & 0.9035 \\
& $\mathrm{LM}=10.36884$ & 0.6780 \\
& $\mathrm{LM}=6.315022$ & 0.3215 \\
& $\mathrm{LM}=11.92664$ & 0.7080 \\
& $\mathrm{LM}=14.36387$ & 0.2175 \\
& $\mathrm{LM}=4.843692$ & 0.1100 \\
& $\mathrm{LM}=4.111327$ & 0.8477 \\
& $\mathrm{LM}=12.03275$ & 0.9039 \\
\end{tabular}

\section{Conclusions and Recommendations}

According to this study, there is no cointegration between variables what is meant that, there is no long run relationship.

For short run analysis, lead-lag relationship between variables is tested with VAR Granger Causality method. It is found that, GDP leads building production and building production Granger causes non-building production, not vice versa.

Since in literature there is no certain consensus about this topic, this result is contrary to some studies but at the same time it supports some works like, Tse and Ganesan (1997) since they also find that, there is unidirectional causality runs from GDP to Construction Flows in short run for the case of Hong Kong.

Furthermore, it can be said that, a change in GDP initially affects building construction projects, and then when new buildings are constructed, the need for some non-building production emerged like; water supply, electricity, fiber internet system etc.. Moreover, with an increase of new residential buildings which are constructed outside the city center, the need of new roads and means of transportation like railways, subways etc. emerged and this triggers an increase in non-building construction projects. Therefore, the causality runs from GDP to Building Production and Building Production to Non-Building Production.

According to this analysis, economic growth strategy based on mainly construction sector is not a good idea since they are not related with each other in long run. And the reason of increase in construction project in recent years is, the rate of increase in GDP. It can be explained that, in the view of consumer, when GDP increases, the consumers get richer and after a certain level increase in their wealth, they want to be a home owner. With this way the demand of housing increases and this triggers an increase in new building projects and this also causes an increase in nonbuilding construction production. From the view of producer or investor, when GDP increases, the production and investment opportunities also increases and they produce new buildings and again with an increase in building production, non-building production also increases because of the reason explained above.

However it should be stated that, this study includes limited data because of lack of data availability about construction sector. Also some other variables may be included to this analysis like; interest rates since it may affect producer or investor decisions. In subsequent studies, these steps can be taken for detailed analysis. Therefore, the results of this study are not conclusive but suggestive. 


\section{References}

Aadland, D., 2002. "Detrending Time- Aggregated Data," Winter Meetings of the Econometric Society, Washington D.C.

Anaman, K.A. and Amponsah, C.O., 2007. "Analysis of the causality links between the growth of the construction industry and growth of macro-economy in Ghana," Construction Management and Economics, Vol. 25, pp. 951-961.

Bon, R., 1992. "The Future of International Construction: Secular Patterns of Growth and Decline," Habitat International, 16(3), pp. 119-128.

Chang, T. and Nieh, C.C., 2004. "A note on testing the causal link between construction activity and economic growth in Taiwan," Journal of Asian Economics, Vol. 15, pp. 591-598.

Choy, C.F., Skitmore, M., Runeson, G. and Bridge, A., 2011. "Property Investment, Construction and Economic Growth: The Case of Malaysia"

Ewing, B.T. and Wang, Y., 2005. "Single housing and macroeconomic activity: an application of generalized impulse response analysis," Applied Economics Letters, Vol. 12, pp. 187-190.

Granger, C.W.J., 1969. "Investigating Causal Relations by Econometric Models and Cross-spectral Methods," Econometrica, Vol. 37, No. 3, pp. 424-438.

Granger, C.W.J., 1988. "Some Recent Development in a Concept of Causality," Journal of Econometrics, Vol. 39, pp. 198-211.

Groak, S., 1994. "Is construction an industry? Notes towards a greater analytic emphasis on external linkages," Construction Management and Economics, Vol. 12, pp. 287-293.

Hongyu, L., Park, Y.N. and Siqi, Z., 2002. "The Interaction between Housing Investment and Economic Growth in China," International Real Estate Review, Vol. 5, No. 1, pp. 40-60.

Ivanov, V. and Kilian, L., 2005. "A Practitioner's Guide to Lag Order Selection for VAR Impulse Response Analysis," Studies in Nonlinear Dynamics \& Econometrics, Vol. 9, Issue 1, Article 2.

Johansen, S., 1988. "Statistical Analysis of Cointegration Vectors," Journal of Economic Dynamics and Control, Vol. 12 , pp. 231-254.

Johansen, S. and Juselius, K., 1990. "Maximum Likelihood Estimation and Inference on Cointegration- With Applications to the Demand for Money," Oxford Bulletin of Economics and Statistics, Vol. 52, No. 2, pp. 0305-9049.

Johansen, S., 1991. "Estimation and Hypothesis Testing of Cointegration Vectors in Gaussian Vector Autoregressive Models," Econometrica, Vol. 59, No. 6, pp. 1551-1580.

Kaya, V., Yalçınkaya, Ö. and Hüseyni, I., 2013. "Role of Construction Sector in Economic Growth: The Case of Turkey (Turkish)," Atatürk University Faculty of Economics, Vol. 27, No. 4, pp. 148-167.

Khan, R.A., 2008. "Role of Construction Sector in Economic Growth: Empirical Evidence from Pakistan Economy," First International Conference on Construction in Developing Countries.

Luetkepohl, H., 2011. "Vector Autoregressive Models," European University Institute Working Papers.

Mallick, H. and Mahalik, M.K., 2008. "Constructing the Economy: The Role of Construction Sector in India's Growth,” J Real Estate Finan Econ, Vol. 40, pp. 368-384.

Ozkan, F., Ozkan, O. and Gunduz, M., 2012. "Causal relationship between construction investment policy and economic growth in Turkey," Technological Forecasting \& Social Change, Vol. 79, pp. 362-370.

Phillips, P.C.B. and Perron, P., 1988. "Testing for a Unit Root in Time Series Regression,” Biometrika, Vol. 75, No. 2, pp. 335-346. 
Schwarz, G., 1978. "Estimating the Dimension of a Model," The Annals of Statistics, Vol. 6, No. 2, pp. 461-464.

Tiwari, A.K., 2011. "A Causal Analysis Between Construction Flows and Economic Growth: Evidence from India," Journal of Business and Economy, Vol. 12, No. 2, pp. 27-42.

Toda, H.Y. and Phillips, P.C.B., 1993. "Vector Autoregressions and Causality," Econometrica, Vol. 61, No. 6, pp. 1367-1393.

Tse, R.Y.O. and Ganesan, S., 1997. "Causal relationship between construction flows and GDP: evidence from Hong Kong," Construction Management and Economics, Vol. 15, pp. 371-376.

Turin, D.A., 1978. "Construction and Development," Habitat International, Vol. 3, No. 12, pp. 33-45.

Zivot, E. and Wang, J., 2006. Modelling Financial Time Series with S-PLUS, Second Edition, New York: Springer. 